\title{
DIVERSIFICATION OF NGOS' REVENUES: IMPLICATIONS FOR THE MISSION CHANGEABILITY
}

\begin{abstract}
Growing social needs and changes in the governmental policy aimed at reducing social aid spending have put pressure on non-profits to develop strategies to gain financial support from diversified sources. Diversification of funding' sources gives the chance not only to increase revenues, strengthening the stability and predictability of NGOs' functioning but also to limiting the control of public and private donors, especially when any of them predominates in capital contributions. The access to many different sources of revenue may reduce changeability of organizations' mission and lead to a larger organizational autonomy in their mission related work. The objective of the article is to examine which sources of NGOs' funding, including public, private internal and external sources are significant factors for the changeability of mission of non-governmental organizations. Data for the analyses have been collected from the national survey of Polish non-governmental organizations. To achieve this aim factor analysis was carried out. This research find that public support or commercial activities are not significant factors regarding the volatility of the non-governmental mission. The only significant variable, from the point of view of decision-making on changing the mission of NGOs, is the external private financing. The obtained results may contribute to the ongoing discussion on the impact of particular types of sources of revenues in the structure of financing NGOs for the implementation of the social mission. The results may provide some indications for those responsible for organizational development strategies.
\end{abstract}

Keywords: NGOs; mission volatility, diversification of revenues, financial sources.

\section{INTRODUCTION}

The main aim of activity of non-governmental organizations (NGOs) refers to fulfilling mission. Therefore, the concept of NGOs is widely used in relation to those organizations which provide a certain form of social work and do not belong to a sector of commercial and governmental entities. The lack of affiliation with the latter is a base to define NGOs (Salamon et al., 2000). Effective functioning of non-governmental organizations increasingly depends on financial sources which support their social goals. The activity of NGOs is not oriented towards profit, which is one of their basic characteristics. The funds necessary to accomplish the long-term idea, aiming at supporting the society, are mainly the resources gained from public and private donors (Enjolras, 2002; Maier et al. 2016).

Undertaking the strategy based on diversification of revenues is perceived as a chance to increase revenues, strengthening the stability and predictability of NGOs' functioning.

\footnotetext{
${ }^{1}$ Paweł Mikołajczak, DSc PhD, Associate Prof. UEP, Department of Money and Banking, Poznań University of Economics and Business, al. Niepodległości 10, 61-875 Poznań; e-mail: pawel. mikolajczak@ue.poznan.pl. ORCID: 0000-0002-7662-2565.
} 
Moreover, additional possibilities of capital contribution can lead to a larger organisational autonomy in their mission related work, which, at the same time, may result in more efficient monitoring of NGOs' functioning (Carroll \& Stater, 2009; Chang \& Tuckman, 2010).

Diversification of revenue sources also gives the chance of limiting the control of public and private donors, especially when any of them predominates in capital contributions. Therefore, it increases the independence of organisations in fulfilling their public mission and at the same time decreases the risk of pressure put on NGOs' managers to change or give up the organisation's mission (Mikołajczak, 2018).

The factor analysis was carried out to achieve the objective of the article that is indicating which sources of revenues of NGOs, including public, internal and external private financing are significant factors for the volatility of social mission of non-governmental organizations.

At the initial stage, some key notions related to the diversification of NGOs' revenues are explained. Secondly, research methodology, including data, research methods are described. Thirdly, the paper analyzes which category of NGOs' revenues is significant factor for the changeability of NGOs' mission. Based on literature and own studies discussion is undertaken. Finally, the author draws conclusions and presents suggestions for further research.

\section{LITERATURE REVIEW}

NGOs' activity is not oriented towards profit, which is one of their basic characteristics. Funding of the mission-oriented goals is mostly obtained from several, diversified sources. Strategy of diversifying revenues in NGOs is overtaken for many reasons that mostly concentrate on widely perceived issues associated with their independence and autonomy within the realization of their social mission. Moreover, revenue diversification support NGOs financial safety and improve their economic potential (Mikołajczak, 2017a).

The dependency of non-profit organisations only on state funding and the lack of alternative sources of revenues means that those organisations become "price-takers" because they have no negotiating power. Therefore, they are forced to accept a weaker market position and adapt to conditions of stronger market participants. They are also more susceptible to co-option with state agencies (Larner \& Craig, 2005).

Access to many different sources of financial capital, on the one hand, limits the adaptation of non-profits to the directions of support imposed by the state policy, and on the other hand, private donors. When any of public or private support leads to capital contributions, diversification of revenue sources gives the chance of limiting the control of public authorities or private. Therefore, it increases the independence of organisations in fulfilling their public mission at the same time, decreases the risk of pressure put on NGOs' managers to change or give up the organisation's priorities (Vaceková et al., 2016).

Carroll and Stater (2009) point out that non-profits with diverse revenue streams are less volatile and therefore less susceptible to environmental forces, for example during recession. In the same context Hager (2001) indicates that revenue diversification increases the probability of organisation's survival. At the same time, authors claim that the higher level of revenue concentration the greater danger of collapse of many organisations, especially during the economic recession when the decrease of revenues from one source could have been substituted from other financial sources. 
Chang and Tuckman (1994) examine determinants of non-profits' ability to diversify revenues and its consequences. They argue that non-profits do not rely on a single revenue source, however their revenues are relaively concentrated. In other publication, authors emphsise that it increases the autonomy of organisations in fulfilling their social mission and reduces the pressure on non-profit managers to change or give up the organisation's goals (Han, 2017).

Mayer, Wang, Egginton and Flint (2012) study the relations between revenue diversification and volatility of mission for non-profits. Authors undermine previous research suggesting that access to many different sources of revenue reduces changeability of organizations. Such effect depends on the structure of portfolio.

Mikołajczak (2017b) examines the significance of non-governmental organisations' particular revenues, affecting the mission-related scale of their activity. On the basis of ranking of financing sources of polish non-governmental organisations, he points out that national and foreign public funds are the most important for those organization, considering the scale of their social activity. Moreover, private sources in a form of revenues from financial and non-financial assets clearly become increasingly important. However, revenues from commercial revenue do not play a key role for the scale of NGOs' activity.

Fischer, Wilsker and Young (2011) indicate that non-governmental organizations providing a wide range of services and products require different sources of financing. They argue that "the sources of funding are related to the services a non-profit provides - specifically whether services are public, private, or mixed in the nature of their benefits".

The way in which non-profits use their chance to provide services is reflected by their social mission. Those entities try to gain financial resources and at the same time to fulfil the adopted aims which serve a specific social group. Weisbrod (1998) argues that the prices of services can be determined in various ways, on a market level, which enables gaining commercial revenue allocated for social mission. On the other hand, they are on the level lower than marginal costs or even on a zero level for targeted consumers (e.g. the unemployed, the sick or people remaining at the margin of social life).

Increasing expectations regarding non-profit organisations, so that they become more business-like, are a subject of a debate, mainly in the USA. Especially the commercial way of gaining financial resources by non-profit organisations causes controversy among many researchers. Many of them believe that it is a necessary reality which all non-profit organisations must accept to operate effectively, and most of all to fulfil their social mission (Sanders \& McClellan, 2014).

However, the discussion on economisation of non-profit sector does not lack the criticism relating to financing which originates in commercial activity led by non-profit entities. That criticism refers mostly to a corrosion of a social mission which can often alter or can even be desisted (Foster \& Bradach, 2005). As Weisbrod (2000) indicates "This increase in commercial activities in the non-profit sector raises the questions of whether non-profit organizations are merely for-profits in disguise". Therefore, that threat results from the possibility of social activity being dominated by economic activity and, thereby, transforming a non-profit organisation into a commercial one, to the detriment of realisation of goals and their social mission (Tuckman, 1998). 


\section{METHOD AND DATA}

Data for the analyses are collected from the Klon/Jawor Association, which conducted a survey on a representative sample of 3,800 Polish foundations and associations run in the third and fourth quarter of 2015. The survey, commissioned by the Klon/Jawor Association, was conducted by the Millward Brown company. The research was carried out on a random group of associations and foundations drawn from the REGON GUS register (Main Statistical Office) (using December 2014 data), verified on the basis of information obtained from KRS (National Court Register) and data collected in the bazy.ngo.pl network. The data concerning associations and foundations were collected by means of the interview method, which used two research techniques: 1) 2,975 interviews were carried out employing the CAPI technique (direct interviews supported by a computer, conducted by interviewers in an area), 2) 825 interviews were done applying the CAWI technique (an online survey). In both cases, respondents were people performing key functions in their organizations. Therefore, the questionnaire was to be completed by the leader of the organization, a member of the senior management, or a member of the trustee board or management committee. The data were collected in compliance with the secrecy principle. As part of the report, in the third quarter of 2014, 24 individual in-depth interviews with non-governmental organization employees and leaders were conducted

The paper used factor analysis which was aimed at determining those variables which were significant regarding the changes of NGOs social mission. As part of the applied method, the weights of components representing partial correlations were calculated, i.e. weights described with values from -1 to 1 , occurring between the analysed variables and the main components. The effect of the analysis was to obtain a loading system for factors distinguished by high loadings for some variables and low for others. The study used varimax rotation, which maximizes the variance of the output space of specific variables, in order to minimize the number of variables necessary to explain a given factor (see: Czopek 2013; Larose, 2008). As a result, a group of factors was grouped, to which the variables most strongly correlated with the appropriate factor were assigned. The factor of the correlation between a given variable and the separated factor was the factor loading. It was assumed that the variables that will be included in the newly created components should have a factor charge value of at least 0.70 .

Among the surveyed entities, 3432 organisations were chosen which had at least one of the financing listed in the survey. The latter were divided into three categories: external public financing, external private financing and internal private financing (see table 1).

Table 1. Categories of NGOs' financing

\begin{tabular}{|l|}
\hline \multicolumn{1}{|c|}{ Categories of financing } \\
\hline Public financing \\
\hline - EU funding \\
- Programmes of the European Commission \\
- Foreign funding (excluding EU) \\
- Central government and administration \\
- Local council \\
\hline
\end{tabular}


Table 1 (cont.). Categories of NGOs' financing

\begin{tabular}{|l|}
\hline \multicolumn{1}{|c|}{ Categories of financing } \\
\hline External private financing \\
\hline - Public fund-raising revenues \\
- Financial and non-financial donations from private individuals \\
- Financial and non-financial donations from institutions, companies \\
- Revenues from $1 \%$ of the income tax \\
- Support from other national NGOs \\
- Support from other foreign NGOs \\
\hline Internal private financing \\
\hline - Membership fees \\
- Interests, profits from endowment capital, deposits, shares and stocks \\
- Revenue from assets \\
- Revenue from commercial activity (sale of products and services) \\
- Revenue from paid-activity of the third sector (excluding businesses) \\
- Punitive damages \\
- Other sources
\end{tabular}

Source: own elaboration on the basis of a survey data of Klon/Jawor Association research on "Condition of the third sector in Poland in 2015"; calculations run in STATISTICA 12.

\section{EMPIRICAL RESULTS}

Four variables (factors) were identified: external public financing, external private financing, internal private financing and a change of mission on a scale of 1 to 5 . All variables were standardised and eigenvalues of each factor were calculated. Using the Keiser criterion (the eigenvalue of a factor > 1) two factors were chosen for further analysis. To examine the structure of variables, their factor loadings were calculated using varimax rotation. The following factor loadings for analysed variables were obtained (see table 2):

Table 2. Factor loadings for analysed variables

\begin{tabular}{|l|l|l|}
\hline \multicolumn{1}{|c|}{ Specification } & Factor 1 & Factor 2 \\
\hline Mission change & 0.015578 & -0.935331 \\
\hline External public financing & 0.688146 & -0.343933 \\
\hline External private financing & 0.724457 & 0.041958 \\
\hline Internal private financing & 0.625590 & 0.231851 \\
\hline
\end{tabular}

Source: own elaboration on the basis of a survey data of Klon/Jawor Association research on "Condition of the third sector in Poland in 2015"; calculations run in STATSTICA 12.

According to the above results, factor 1 is represented only by one variable, i.e. external private financing and factor 2 is represented by the variable mission change. The choice of variables was determined by the level of factor loadings which had to exceed the level of 0.70. It means that in the examined group there exists a structure of factors assuming two groups of characteristics which are as follows: mission change and external private financing. Interpreting the obtained results, it can be assumed that among three kinds of NGOs 
financing (public - internal or external and private - external) only the latter is a significant variable from the point of view of decision-making on NGOs mission change. Public financing (e.g. grants) or running a business and obtaining commercial revenues do not play an important role regarding the change of NGOs mission.

\section{DISCUSSION}

The paper corresponds with the international discussion on diversification of financial sources of non-profit organisations. Research and analyses reflect distinct features of nonprofit sector operating in societies of a big commercial importance. Non-profit activities in each national or cultural context must operate within global market economy. Those arrangements can provide a Polish accent for empirical understanding, in the debate on the significance of financial sources of non-profit organisations with regard to the realization of their mission. Especially, previous researchers demonstrate a wider use of commercial actions in the non-profit sector (Foster \& Bradach, 2005). The research of Anglo-Saxon NGOs prevails the view on the corrosive consequences of commercial revenues on the NGOs' social mission (i.e. Eikenberry \& Kluver, 2004). In turn, few studies from Central and Eastern Europe indicate that commercial revenues stimulate the missionary activity of non-governmental organizations (i.e. Vecekova et al., 2016). A lot of authors indicate increasing dependence of non-profits' activity on public policy reflecting in government directions of support (Hodgkinson, et al, 1992; Young, 2003; Kerlin \& Pollak, 2011). In contrast with existing literature which claims that the commercial funding and public support are essential for the realization of NGO's social mission of non-profits, this research finds that public support or commercial activities are not significant factors regarding the volatility of the social mission in Polish NGOs' sector. On the other hand, study support some results of other researchers indicating relations between social mission and private external donations (i.e Mayer et al, 2014).

\section{CONCLUSIONS}

Diversification of non-profits funding represent their answer to numerous challenges in changing surrounding of that sector. As many researchers indicate, from the financial point of view, gaining revenues by non-governmental organizations from many different sources seems to be a justified choice. It constitutes the chance to increase their revenues, strengthens their financial stability and functioning predictability of NGOs. At the same time, the variability of revenues and the threat of being overtaken by bigger entities, are limited. Moreover, the differentiation of possibilities of capital input, can lead to a bigger organisational autonomy. It contributes to a more efficient control over the activity connected with mission fulfilment.

The results of empirical analysis prove that among three sources of NGOs' financing (public, internal and external private) the only significant variable, from the point of view of decision-making on changing the mission of NGOs, is the external private financing, which includes the revenues generated in public fund-raising, financial and non-financial donations from institutions and companies and $1 \%$ of income tax. Revenue on commercial activity (sale of products and services) does not play any vital role in case of the change of NGOs' mission. Similarly, does not public financing, both on a national and local level, as well as foreign funds. 
In the discussion on the role of financial sources of NGOs referring to mission changeability further research efforts are needed. Although the investigated sources of funding constitute all categories of revenues that are achieved by Polish NGOs, the author is aware that they do not constitute the entire spectrum of revenues obtained by foreign non-profits. Moreover, realization of social mission is influenced by a lot of factors. Certain modifications of social mission implemented by NGOs are necessary and reflect to evolving social needs. However, the research results presented here may be developed and offer useful guidance to those in charge of the running of non-governmental organizations. The presented findings constitute certain contribution to the discussion about diversification of revenue sources and its significance for mission of social organisation.

\section{REFERENCES}

Carroll, D.A., Stater, K.J. (2009). Revenue diversification in non-profit organizations: does it lead to financial stability? "Journal of Public Administration Research and Theory”, No. 19(4). DOI: 10.1093/jopart/mun025.

Chang, C.F., Tuckman, H.P. (1994). Revenue diversification among non-profits. "Voluntas: International Journal of Voluntary and Non-profit Organizations", No. 5(3). DOI: 10.1007/BF02354036.

Czopek, A. (2013). Analiza porównawcza efektywności metod redukcji zmiennych - analiza składowych głównych i analiza czynnikowa, ,Studia Ekonomiczne”, No. 132 Zastosowania metod matematycznych w ekonomii i zarzadzaniu.

Eikenberry, A.M., Kluver, J.D. (2004). The marketization of the non-profit sector: civil society at risk? "Public administration review", No. 64(2). DOI: 10.1111/j.1540-6210.2004.00355.

Enjolras, B. (2002). The commercialization of voluntary sport organizations in Norway. "Nonprofit and Voluntary Sector Quarterly”, No. 31(3). DOI: $10.1177 \% 2$ F0899764002313003.

Fischer, R.L., Wilsker, A., Young, D.R. (2011). Exploring the revenue mix of non-profit organizations: Does it relate to publicness? "Non-profit and Voluntary Sector Quarterly", No. 40(4). DOI: $10.1177 \% 2 F 0899764010363921$.

Foster, W., Bradach, J. (2005). Should non-profits seek profits? "Harvard Business Review", No. 83(2).

Frances, N. (2008). The End of Charity. Time for Social Enterprise, London: England, Allen and Unwin.

Froelich, K.A. (1999). Diversification of revenue strategies: Evolving resource dependence in non-profit organizations. "Non-profit and Voluntary Sector Quarterly", No. 28(3). DOI: $10.1177 / 0899764099283002$.

Hager, M. (2001). Financial vulnerability among arts organizations: A test of the Tuckman-Chang measures. Non-profit and Voluntary Sector Quarterly, No. 30(2). DOI: $10.1177 / 0899764005282482$.

Han, J. (2017). Social Marketisation and Policy Influence of Third Sector Organisations: Evidence from the UK. Voluntas, International Journal of Voluntary and Non-profit Organizations", No. 28. DOI: 10.1007/s11266-017-9853-1.

Hodgkinson, V.A., Weitzman, M.S., Toppe, C., Noga, S. (1992). Non-profit almanac 19921993. San Francisco: Jossey Bass.

Larose, D.T. (2008). Metody i modele eksploracji danych. Warszawa: Wydawnictwo Naukowe PWN. DOI: 10.1002/0471756482. 
Larner, W., Craig, D. (2005). After neoliberalism? Community activism and local partnerships in Aotearoa New Zealand. “Antipode”, No. 37(3). DOI: 10.1111/j.0066-4812.2005.00504.x.

Maier, F., Meyer, M., Steinbereithner, M. (2016). Non-profit Organizations Becoming BusinessLike A Systematic Review. "Non-profit and Voluntary Sector Quarterly", No. 45(1). DOI: $10.1177 \% 2 \mathrm{~F} 0899764014561796$.

Mayer, W.J., Wang, H., Egginton, J.F., Flin, H.S. (2014). The Impact of Revenue Diversification on Expected Revenue and Volatility for Non-profit Organizations. "Non-profit and Voluntary Sector Quarterly”, No. 42(2). DOI: 10.1177\%2F0899764012464696.

Mikołajczak, P. (2017a). Źródta i instrumenty finansowego wsparcia przedsiębiorstw społecznych. Poznań: Wydawnictwo UEP.

(2017b). Importance of funding sources to the scale of activity of social enterprises. "Finanse, Rynki Finansowe, Ubezpieczenia”, No. 4(88). DOI: 10.18276/frfu.2017.88/2-14.

- (2018). The impact of the diversification of revenues on NGOs' commercialization: evidence from Poland. "Equilibrium. Quarterly Journal of Economics and Economic Policy", No. 13(4). DOI: 10.24136/eq.2018.037.

Salamon, L.M., Hems, L.C., Chinnock, K. (2000). The non-profit sector: For what and for whom? (Working papers of the Johns Hopkins Comparative Non-profit Sector Project No. 37). Baltimore, MD: The Johns Hopkins Center for Civil Society Studies.

Sanders, M.L., McClellan. J.G. (2014). Being Business-Like While Pursuing a Social Mission: Acknowledging the Inherent Tensions in US Non-profit Organizing. "Organization", No. 21(1). DOI: $10.1177 / 1350508412464894$.

Tuckman, H.P. (1998). Competition, commercialization, and the evolution of non-profit organizational structures. "Journal of Policy Analysis and Management", No. 17. DOI: 10.1002/(SICI)1520-6688(199821)17:2\%3C175::AID-PAM4\%3E3.0.CO;2-E.

Vaceková, G., Valentinov, V., Nemec, J. (2016). Rethinking non-profit commercialization: the case of the Czech Republic. "International Journal of Voluntary and Non-profit Organizations Voluntas". DOI: 10.1007/s11266-0169772-6.

Weisbrod, B.A. (2000). To profit or not to profit: The commercial transformation of the nonprofit sector, Cambridge University Press.

(1998). The non-profit mission and its financing. "Journal of Policy Analysis and Management”, No. 17. DOI: 10.1002/(SICI)1520-6688(199821)17:2\%3C165::AID-PAM3\%3E3.0. $\mathrm{CO} ; 2-\mathrm{F}$.

Zimmerman, B., Dart, R. (1998). Charities doing commercial ventures: Societal and organizational implications, Toronto, Ontario, Canada, Trillium Foundation.

Young, D.R. (2003). New trends in the US non-profit sector: Towards market integration? In OECD (Ed.), The non-profit sector in a changing economy. Paris: OECD.

DOI: $10.7862 /$ rz.2019.hss.18

The text was submitted to the editorial office: January 2019.

The text was accepted for publication: June 2019. 